Zeolites and Related Materials: Trends, Targets and Challenges. Proceedings of 4th International FEZA Conference. A. Gedeon, P. Massiani and F. Babboneau (Editors) (C) 2008 Elsevier B.V. All rights reserved.

\title{
SYNTHESIS OF HIGH SILICA CHA ZEOLITES WITH CONTROLLED $\mathrm{Si} / \mathrm{Al} \mathrm{RATIO}$
}

\author{
E. A. Eilertsen(a), M. H. Nilsen(b), R. Wendelbo(c), U. Olsbye(d), K. P. Lillerud(d) \\ a Department of Chemistry, University of Oslo, P.O. Box 1033, Blindern, N - 0315 Oslo \\ $b$ Center for Materials Science and Nanotechnology, Department of Chemistry, University of Oslo, Norway \\ c Abalonyx AS, c/o Department of Chemistry, University of Oslo, Norway \\ $d$ InGap, Department of Chemistry, University of Oslo, Norway
}

\begin{abstract}
Zeolites with the CHA topology have been synthesized with $\mathrm{Si} / \mathrm{Al}$ ratios ranging from 15 to 133 . ICPAES analysis shows that the $\mathrm{Si} / \mathrm{Al}$ ratio in the material is close to linearly related to the $\mathrm{Si} / \mathrm{Al}$ ratio in the reaction mixture, while powder XRD shows that the unit cell parameters decrease with increasing $\mathrm{Si} / \mathrm{Al}$ ratio. The difference between the unit cell parameters for the as-synthesized and the calcined samples show that the structure directing agent sterically hinders the contraction in the c-axis direction for the as-synthesized samples. A relationship between the $\mathrm{Si} / \mathrm{Al}$ ratio in the material and the a-axis has been established. The particle size of the material also shows a dependency on the Si/Al ratio of the material.
\end{abstract}

Keywords: SSZ-13, Si/Al ratio, Chabazite, CHA, High silica.

\section{Introduction}

Zeolites with the CHA topology are of industrial interest, primarily as potential highly selective catalysts for application in the methanol to olefins (MTO) reaction [1]. The presence and concentration of $\mathrm{Al}$ in the zeolite framework determines the acidity of the material in the hydrogen form. The main challenge has been to synthesize a material with a low density of acidic sites to avoid a too rapid deactivation. In the early synthesis of CHA zeolites, the material was prepared from an inorganic gel and had typically a Si/Al ratio of less than 3 [2]. SSZ-13 was the first real high silica CHA with $\mathrm{Si} / \mathrm{Al}$ ratio of about 12, synthesized with N, N, N-trimethyl-1-adamantammonium hydroxide (TMAdaOH) as structure directing agent [3]. This was reported in 1985, while a pure $\mathrm{SiO} 2$ CHA was reported in 1998 [4]. For the pure $\mathrm{SiO} 2 \mathrm{CHA}$, the unit cell parameters were determined to be: $a=13.529 \AA$ and $c=14.748 \AA$ [4]. In addition, several patents on high silica CHA materials have been published $[5,6]$. The application of CHA zeolites in the MTO reaction with $\mathrm{Si} / \mathrm{Al}$ ratios ranging from $14-67$ was studied by Zhu et al. in 2007 [7].

\section{Experimental}

The materials were prepared from an unseeded reaction mixture forming a gel with the following composition: 10 TMAda-OH : $7.5 \mathrm{Na}_{2} \mathrm{O}: 5 \mathrm{~F}-:$ : 0.3-2.7 $\mathrm{Al}_{2} \mathrm{O}_{3}: 100 \mathrm{SiO}_{2}: 2200 \mathrm{H}_{2} \mathrm{O}$. The gel was prepared by first mixing solutions of $\mathrm{NaOH}(1 \mathrm{M})$, TMAdaOH $(0.77 \mathrm{M})$ and deionized water.

$\mathrm{AlOOH} \cdot \mathrm{xH}_{2} \mathrm{O}$ and $\mathrm{NaF}$ was then added to the solution and stirred until the powder was dissolved. This mixture was mixed with Cab-O-Sil M5 fumed silica. The resulting viscous gel was homogenized by hand for 5 minutes and aged at room temperature for 2 hours. The gel was then heated statically for 7 days at $160{ }^{\circ} \mathrm{C}$ in a $15 \mathrm{~mL}$ Teflon lined steel autoclave. The materials were characterized by powder 
X-ray diffraction (XRD), scanning electron microscopy (SEM), and inductively coupled plasma atomic emission spectroscopy (ICP-AES). The unit cell parameters were obtained by Pawley refinement. The $2 \theta$ areas in the diffractograms with quartz peaks were excluded from the refinement.

\section{Results and discussion}

The synthesized materials with different $\mathrm{Si} / \mathrm{Al}$ ratios exhibit the CHA topology as shown in Figure 1. In the XRD patterns for the materials with the highest $\mathrm{Si} / \mathrm{Al}$ ratios, small amounts of quartz are observed as an impurity at $2 \theta=26^{\circ}$. ICP-AES analysis as seen in Figure 2 indicates a nearly linear relationship between the $\mathrm{Si} / \mathrm{Al}$ ratio in the reaction mixture and the $\mathrm{Si} / \mathrm{Al}$ ratio in the material. There is, however, a slight enrichment of $\mathrm{Al}$ in the materials compared to the reaction mixture composition, and at very high $\mathrm{Si} / \mathrm{Al}$ ratios there appears to be a deviation from linearity. The ICP-AES results show that the $\mathrm{Si} / \mathrm{Al}$ ratio for the synthesized materials varies from $15-133$, but with some uncertainty for the samples with the highest $\mathrm{Si} / \mathrm{Al}$ ratios due to the presence of small amounts of quartz.

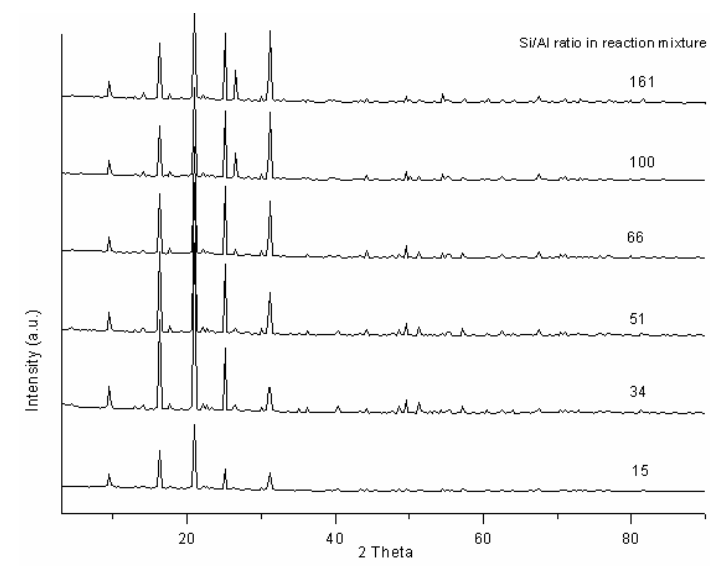

Figur 1: Diffractograms of samples with different $\mathrm{Si} / \mathrm{Al}$ ratio

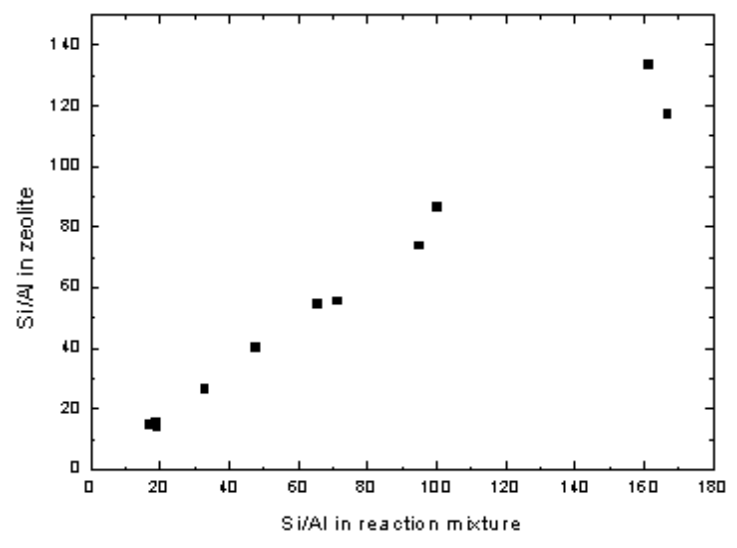

Figur 2: $\mathrm{Si} / \mathrm{Al}$ ratio in the materials determined by ICP$\mathrm{AES}$ as function of the $\mathrm{Si} / \mathrm{Al}$ ratio in the reaction mixture

The synthesis of CHA type zeolites with the TMAda+ cation as structure directing agent is one of the best known examples of templating. In spite of this strong structure directing effect, it has been difficult to synthesize $\mathrm{CHA}$ type materials with $\mathrm{Si} / \mathrm{Al}$ ratios above 12 . Analysis of the variations in unit cell parameters, as seen from Figure 3, shed new light on this intriguing observation. The unit cell parameters decrease, as expected, with a decreasing amount of $\mathrm{Al}$ in the material. This is in

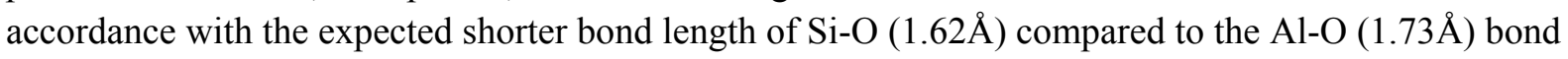
length [8]. It can also be seen that the unit cell parameters for the calcined sample converge to the values for the reported pure $\mathrm{SiO} 2 \mathrm{CHA}$ when the $\mathrm{Si} / \mathrm{Al}$ ratio increases [4]. However, there is a large anisotropic contraction in the as-synthesized material. The $c$-axis is nearly constant while all the relaxation of strain is seen as a large change in the $a$-axis. For the calcined material, the relaxation of strain is seen as a large change in the $c$-axis. This can be explained by the template position in the material as shown in Figure 4. Villaescusa et al. [9] showed that the template is oriented parallel or antiparallel to the $c$-axis. In the as-synthesized samples the template thus sterically hinders the decrease in the $c$-axis, while for the calcined samples there is no such hindrance. Therefore the $c$-axis is free to decrease for the calcined samples. Strong templating effect relies on a perfect match between voids in the lattice and the template, which seems to be the case at low Si/Al ratios. It appears however, that the higher the $\mathrm{Si} / \mathrm{Al}$ ratio, the more strain of the CHA lattice, resulting in less favorable conditions for crystal growth. 

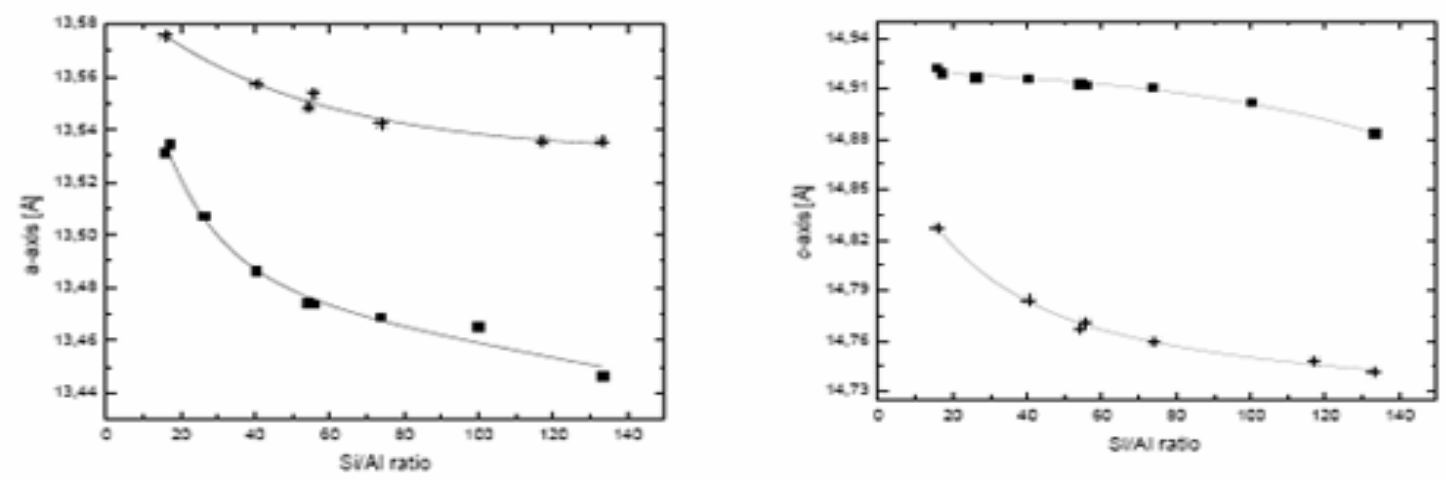

Figure 3: Unit cell parameters for as-synthesized samples (square) and for calcined samples (star) as a function of the $\mathrm{Si} / \mathrm{A} 1$ ratio

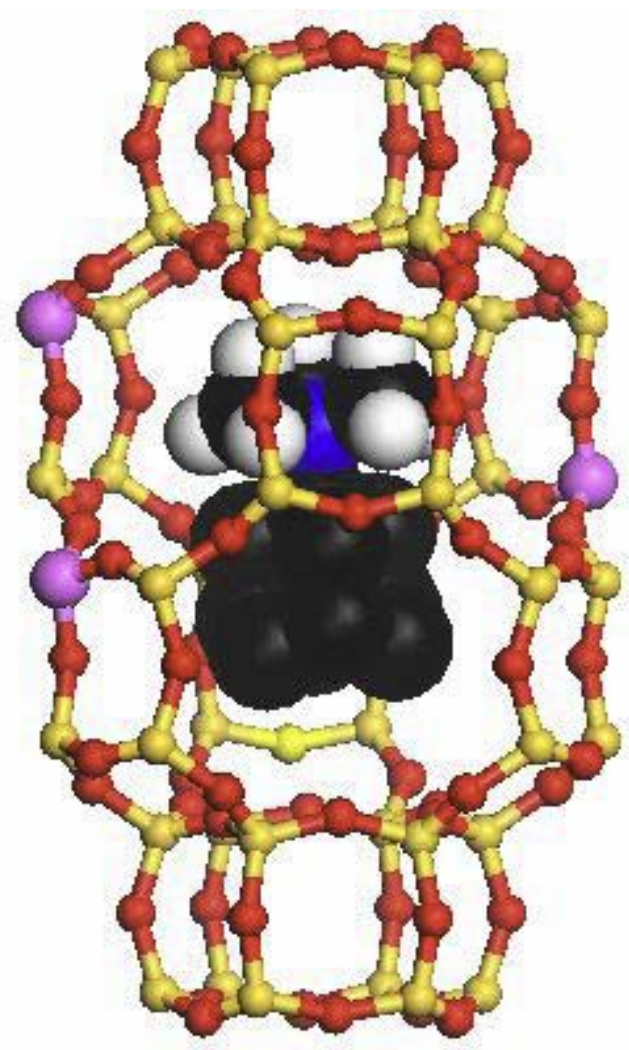

Figure 4: CHA cage with template
Another possible explanation for the difficulty of synthesizing the material over a large compositional range is that when the $\mathrm{Si} / \mathrm{Al}$ ratio increases, the network takes a more neutral charge. For the structure to be electrically neutral there must be charge compensation to provide charge balance between the framework and the positively charged template. This can either be accomplished by occluded anions or lattice defects. Villaescusa et al. [9] showed that an Fanion is located in the double 6-ring in the CHA structure for the pure $\mathrm{SiO} 2 \mathrm{CHA}$ providing for charge balance. We note here that our attempts of making the material without $\mathrm{F}$ - led to a phase mixture of CHA and an unknown phase for $\mathrm{Si} / \mathrm{Al}$ ratios above 60 .

By plotting the crystallographic a-axis for the as-synthesized and the calcined materials against the $\mathrm{Si} / \mathrm{Al}$ ratio as determined by ICPAES, the plot fits very well to an exponential function as seen in Figure 3. This can be used to determine the $\mathrm{Si} / \mathrm{Al}$ ratio of the material by measuring the unit cell parameters with XRD.

The Si/Al ratio in the material can be determined from XRD by the following relations:

$$
\begin{aligned}
& \frac{S i}{A l}=-35.63 \cdot \ln \left(\frac{(\mathrm{a})-13.45}{0.129}\right) \\
& \frac{\mathrm{Si}}{\mathrm{Al}}=-43.27 \cdot \ln \left(\frac{(\mathrm{a})-13.43}{0.0621}\right)
\end{aligned}
$$


where a is the length of the $a$-axis in $\AA$. Equation 1 gives a relation between the $a$-axis of the assynthesized material and the $\mathrm{Si} / \mathrm{Al}$ ratio, while equation 2 gives the same relation for the calcined material. As can be seen in Figure 5, the particle size is dependent on the Si/Al ratio in the reaction mixture. For the materials with the lowest $\mathrm{Si} / \mathrm{Al}$ ratios, the particle size is about $20 \mu \mathrm{m}$. When the $\mathrm{Si} / \mathrm{Al}$ ratio in the reaction mixture exceeds 50 , there appears to be a step in the particle size. For higher $\mathrm{Si} / \mathrm{Al}$ ratios, the particle size is from 2 to $4 \mu \mathrm{m}$.

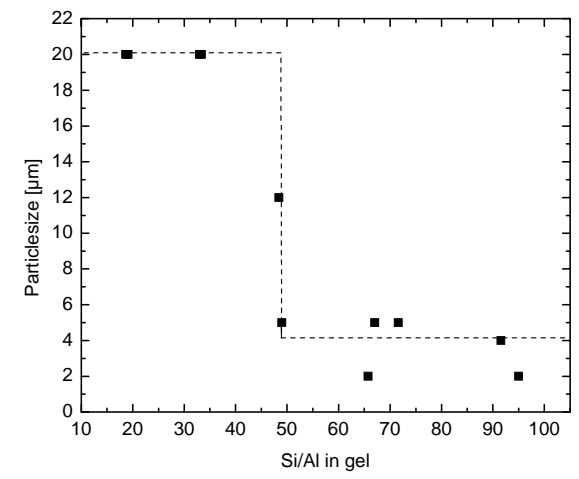

Figure 5: Particle size as function of the $\mathrm{Si} / \mathrm{Al}$ ratio in the reaction mixture

\section{Conclusions}

The results from this work show that it is possible to synthesize zeolites with the CHA topology over a greater compositional range than previously reported, and that it can be controlled by adjusting the reaction mixture composition. The obtained Si/Al ratios have been determined by ICP-AES to be between 15 and 133. The increase in the Si/Al ratio can also be observed by an expected decrease of size the unit cell, from which it is possible to calculate the $\mathrm{Si} / \mathrm{Al}$ ratio from an empirically based equation. A particle size dependency of the $\mathrm{Si} / \mathrm{Al}$ ratio in the reaction mixture has also been observed.

\section{References}

[1] Yuen, L.T.; Zones, S.I.; Harris, T.V.; Gallegos, E.J.; Auroux, A. Microporous Mater., 2 (1994) 105-117

[2] Barrer, R. M. Zeolites, 1 (1981) 130-140

[3] Zones, S. I. US patent 4,544,538 (1985)

[4] Dìa-Cabañas, M.J.; Barret, P.A.; Camblor, M.A. Chem. Commun. (1998) 1881-1882

[5] Cao, G.; Mertens, M.M. US Patent WO 2005/063623 (2005)

[6] Yuen, L.T. US Patent WO 2006/057760 (2006)

[7] Zhu, Q.; Kondo, J.N.; Ohnuma, R.; Kubota, Y.; Yamaguchi, M.; Tatsumi, T. Micropor. Mesopor. Mater., (2007) doi:10.1016/j.micromeso.2007.09.026

[8] Jentys, A.; Lercher, J.A.; in: van Bekkum, H.; Flanigen, E.M.; Jacobs, P.A.; Jansen, J.C. (Eds.), Introduction to Zeolite Science and Practice, Studies in Surface Science and Catalysis, Vol. 139, Elsevier, Amsterdam (2001) 364

[9] Villaescusa, L.A.; Bull, I.; Wheatley, P.S.; Lightfoot, P.; Morris, R.E, J. Mater. Chem., 13 (2003) 1978-1982 